\title{
Evaluation of prevention and control measures for ventilator- associated pneumonia
}

\author{
Leandra Terezinha Roncolato da Silva ${ }^{1}$ \\ Ana Maria Laus ${ }^{2}$ \\ Silvia Rita Marin da Silva Canini² \\ Miyeko Hayashida ${ }^{3}$
}

This study aimed to evaluate the quality of health care delivered in an Intensive Care Unit, concerning the use of pneumonia prevention and control measures in high-risk patients on mechanical ventilation. In this descriptive and exploratory research, 839 observations of patients under invasive ventilation care were carried out, between November 2009 and January 2010, using the Indicator of Evaluation of Adherence to Prevention and Control Measures in High-risk Patients (IRPR). Some isolated measures that compose the mentioned indicator reached rates close to $100 \%$, but the general compliance rate with all prevention and control measures of ventilator-associated pneumonia was $26.94 \%$. It is concluded that, although the evaluated practices are accomplished at the unit, systematic evaluations of the interventions is needed so as to permit the discussion and practice of other educational strategies by the health team.

Descriptors: Quality Indicators, Health Care; Pneumonia, Ventilator-Associated; Nursing; Health Evaluation.

\footnotetext{
${ }^{1}$ RN, M.Sc. in Nursing, Hospital das Clínicas, Faculdade de Medicina de Ribeirão Preto, Universidade de São Paulo, SP, Brazil. E-mail: leandra_enf@yahoo.com.br.

2 RN, Ph.D. in Nursing, Professor, Escola de Enfermagem de Ribeirão Preto, Universidade de São Paulo, WHO Collaborating Centre for Nursing Research Development, SP, Brazil. E-mail: Ana Maria - analaus@eerp.usp.br, Silvia - canini@eerp.usp.br.

${ }^{3}$ RN, Ph.D. in Nursing, Escola de Enfermagem de Ribeirão Preto, Universidade de São Paulo, WHO Collaborating Centre for Nursing Research Development, SP, Brazil. E-mail: miyeko@eerp.usp.br.
}

Corresponding Author:

Leandra Terezinha Roncolato da Silva

Rua Maestro Ignácio Stábile, 1161

Bairro: Boa Vista

CEP: 14025-640, Ribeirão Preto, SP, Brasil

E-mail: leandra_enf@yahoo.com.br 


\section{Avaliação das medidas de prevenção e controle de pneumonia associada à ventilação mecânica}

Neste estudo objetivou-se avaliar a qualidade da assistência à saúde prestada em uma unidade de terapia intensiva, quanto ao uso das medidas de prevenção e controle de pneumonia em pacientes de alto risco, submetidos a ventilação mecânica. Trata-se de pesquisa descritiva exploratória, na qual foram realizadas 839 observações de pacientes em assistência ventilatória invasiva, no período de novembro de 2009 a janeiro de 2010, utilizando-se o Indicador de Avaliação da Adesão às Medidas de Prevenção e Controle de Pneumonia em Pacientes de Alto Risco (IRPR). Algumas medidas isoladas que compõem o Indicador alcançaram índices próximos a $100 \%$, porém, o índice da conformidade geral a todas as medidas de prevenção e controle de pneumonia, associada à ventilação mecânica, correspondeu a 26,94\%. Conclui-se que, embora essas práticas avaliadas estejam instituídas na unidade, há necessidade de avaliações sistemáticas das intervenções para que outras estratégias educativas sejam discutidas e implementadas pela equipe de saúde.

Descritores: Indicadores de Qualidade em Assistência à Saúde; Pneumonia Associada a Ventilação Mecânica; Enfermagem; Avaliação em Saúde.

\section{Evaluación de las medidas de prevención y control de neumonía asociada a ventilación mecánica}

Este estudio objetivó evaluar la calidad de la asistencia a la salud prestada en una Unidad de Terapia Intensiva, en lo que se refiere al uso de medidas de prevención y control de neumonía en pacientes de alto riesgo sometidos a ventilación mecánica. Se trató de una investigación descriptiva exploratoria en la cual fueron realizadas 839 observaciones de pacientes en asistencia ventilatoria invasora, en el período de noviembre de 2009 a enero de 2010, utilizando el Indicador de Evaluación de la Adhesión a las Medidas de Prevención y Control de Neumonía en Pacientes de Alto Riesgo (IRPR). Algunas medidas aisladas que componen el Indicador alcanzaron índices próximos a 100\%, sin embargo el índice de la conformidad general en todas las medidas de prevención y control de neumonía asociada a la ventilación mecánica correspondió a 26,94\%. Se concluye que a pesar de que estas prácticas evaluadas estuviesen instituidas en la unidad, hay necesidad de realizar evaluaciones sistemáticas de las intervenciones para que otras estrategias educativas sean discutidas e implementadas por el equipo de salud.

Descriptores: Indicadores de Calidad de la Atención de la Salud; Neumonia Asociada al Ventilador; Enfermería; Evaluación en Salud.

\section{Introduction}

Health institutions have adopted different strategies in recent years to assess services, with a view to obtaining a certification level according to the service quality they offer. According to one study(1), available activities to guarantee the accomplishment of this process can be divided in internal and external, particularly Internal Quality Assessment, Nursing Audit,
Hospital Infection Prevention and Control, Research Ethics, Risk Management, Internal Accident Prevention Commissions and Permanent Education, Client and Hospital Accreditation Services.

Thus, clinical indicators have been increasingly used as essential tools, defined as a continuous or periodical quantitative measure of a given process or system's 
variables, characteristics or attributes, which permits recognizing wanted or unwanted results that can guide the establishment of the best health practices $^{(2)}$.

Indicators can incorporate health quality assessment dimensions $^{(3)}$, i.e. structure, process and outcome, which are mutually complementary to obtain a better quality and contribute to improve the results. The advantage of using one assessment type will depend on the event one intends to measure(2).

Hospital infections $(\mathrm{HI})$ raise morbidity and mortality rates, extend the duration of patients' hospital stay and, consequently, increase costs for health services. Various measures strongly based on scientific evidence exist for their prevention and control, but health professionals' use of these measures is still a great challenge(2).

Regarding cost, three times higher costs have been reported for patients with infection when compared with uninfected patients. Despite the legislation in force in Brazil, $\mathrm{HI}$ rates remain high at $15.5 \%$, corresponding to 1.18 infection episodes per patient hospitalized in Brazilian hospitals ${ }^{(4)}$.

Among the main nosocomial infections, pneumonia stands out, which figures among the five most frequent nosocomial infections in people older than 65 years in the USA and is still considered the main cause of death in developing countries ${ }^{(5)}$.

Pneumonia is the second main nosocomial infection and, at Intensive Care Units (ICU), when associated with mechanical ventilation, it is the infection that most affects hospitalized patients, with incidence rates ranging between $9 \%$ and $68 \%$, depending on the diagnostic method used and the study population(6). This information is in line with the findings of a study ${ }^{(7)}$ that determined $\mathrm{HI}$ incidence at a Brazilian adult ICU, in which pneumonias added up to $25.6 \%$.

Therefore, accomplishing surveillance for mechanical ventilation-associated pneumonia (MVAP), using standardized ICU definitions, calculating MVAP rates and, mainly, associating these rates with pertinent prevention measures are strongly recommended actions. These indicators can turn into an important ally for care quality assessment ${ }^{(8)}$.

In view of the above, it was considered pertinent to accomplish this study, aimed at assessing the health care quality delivered at an ICU regarding the use of pneumonia prevention and control measures in patients under mechanical ventilation care, limited consciousness and/or nutrition through digestive tubes, and at calculating the adherence rate through a clinical indicator.

\section{Methods}

A descriptive and exploratory study with a quantitative approach was accomplished at two Intensive Care Units for adult patients at a large and high-complexity public teaching hospital in the interior of São Paulo state, which delivers care to patients in urgency and emergency situations.

Research subjects were patients hospitalized at these units who were undergoing invasive ventilation care, with a limited consciousness level and/or nutrition through digestive tubes, excluding patients diagnosed with pneumonia upon admission or within the first 24 hours of ICU hospitalization, as well as patients not included due to the family's refusal to participate in the study.

Two instruments were used for data collection. The first covered demographic and clinical data for eligible patients. The second, used as a clinical process indicator, was developed and content validated by a group of experts and made available in the Manual of Assessment Indicators for Hospital infection Control Practices ${ }^{(2)}$. This instrument, called the Indicator of Evaluation of Adherence to Prevention and Control Measures in High-risk Patients (IRPR) is in the public domain and monitors the application of some hospital pneumonia control and prevention measures, which are: raised decubitus (between 30 and $45^{\circ}$ ), respiratory physiotherapy, use of sterile solutions on respiratory therapy equipment and adherence to the routine exchange of inhalers established at the institution. As recommended, other measures can also be incorporated, according to the assessment group.

This indicator contains a worksheet to register the assessments and an operational construct, which describes and orients the application of the assessment to the practice it corresponds to. It involves a concrete operation and indicates what is assessed and how information should be collected and measured, with a view to guaranteeing uniform assessment and legitimacy in empirical data representation, besides presenting the best practice available, scientifically founded, so that adherence rates can be calculated after the assessment ${ }^{(9)}$.

Data were collected between November 2009 and January 2010, at preset times (from 10 to $11 \mathrm{~h}, 15$ to $16 \mathrm{~h}$ and 21 to $22 \mathrm{~h}$ ), involving direct observation and review of notes in the study participants' patient files. Thus, each patient was observed three times per day, from the moment of hospitalization until the case outcome due to discharge, transfer or death. 
With a view to checking the inclination angle of the headrest, a goniometer fixed to the headrests was used, available at the units.

It is highlighted that, due to the practices and responsibility for the type of activities assessed, only the nursing and physiotherapy teams' activities were observed.

To calculate the general adherence rate, according to the IRPR indicator's formula, the total number of observations was considered in which all measures were conforming for the same patient. Thus, it was enough for one of the four measures not to be correctly applied for adherence not to be obtained in that patient.

To calculate the adherence rates for the practices included in the indicator that was applied, the formula recommended in the operational construct was used, as described below, assessing the IRPR's general adherence, as well as adherence for each indicator component.

Total number of patients under ventilatory care and with limited consciousness and/or nutrition through digestive tubes in which all hospital pneumonia control components are correctly applied

Total number of patients assessed under the conditions

described in the numerator

The researcher collected the data together with three nurses experienced in intensive care, who had been properly trained for assessment and data collection.

Approval for the research was obtained from the Institutional Review Board at the study institution (HCRP Process No 11193/2008).

\section{Results}

During the study period, 114 patients were hospitalized at the study hospital's ICU and 38 complied with the inclusion criteria. Male patients predominated (68.4\%) and ages ranged from 19 to 82 years. As for origin, most patients came from the Surgical Unit, with 11 (28.95\%) coming from the Recovery Room and five $(13.16 \%)$ from the Operating Room, while eight $(21.05 \%)$ came from the Care room for patients with multiple traumas. ICU time ranged between one and seven days in $44.74 \%$ of patients.

In total, 839 observations of MVAP prevention and control measures were accomplished according to the IRPR indicator, 277 during the morning and afternoon shifts and 285 at night. This difference was due to the hospitalization and discharge times after the established time for data collection, thus increasing observation opportunities during the night shift. Table 1 shows data for observations in each shift.
Table 1 - Distribution of patient observations in absolute figures and respective general adherence percentages, per work shift, for specific MVAP prevention and control measures, Ribeirão Preto, SP, Brazil, 2009-2010

\begin{tabular}{lccc}
\hline \multirow{2}{*}{ Work Shift } & Total & \multicolumn{2}{c}{ Adherence } \\
\cline { 3 - 4 } & & $\mathbf{n}$ & $\%$ \\
\hline Morning & 277 & 64 & 23.10 \\
Afternoon & 277 & 36 & 13.00 \\
Night & 285 & 126 & 44.21 \\
Total & 839 & 226 & 26.94 \\
\hline
\end{tabular}

General adherence to all MVAP prevention and control measures corresponded to $26.94 \%$, with the highest rate $(44.21 \%)$ found during the night shift.

Table 2 shows adherence and non-adherence to each specific MVAP prevention and control measure, per work shift. It is verified that each isolated measure always obtained a higher adherence rate than the general adherence rate $(26.94 \%)$, which associated all measures per patient. Keeping the headrest raised and physiotherapy care were the measures that most negatively influenced the achievement of general adherence.

Table 3 presents the situations found that determined non-adherence to MVAP prevention and control measures in each work shift. 
Table 2 - Total number of observations and adherence and non-adherence rates for each specific MVAP prevention and control measure, per work shift, Ribeirão Preto, SP, Brazil, 2009-2010

\begin{tabular}{|c|c|c|c|c|c|}
\hline \multirow{2}{*}{ Variables } & \multirow{2}{*}{ Total } & \multicolumn{2}{|c|}{ Adherence } & \multicolumn{2}{|c|}{ Non-Adherence } \\
\hline & & $\mathbf{n}$ & $\%$ & $\mathbf{n}$ & $\%$ \\
\hline \multicolumn{6}{|l|}{ Morning } \\
\hline Use of sterile solution & 277 & 276 & 99.64 & 1 & 0.36 \\
\hline Respiratory therapy material change & 277 & 261 & 94.22 & 16 & 5.78 \\
\hline Physiotherapy care & 277 & 124 & 44.76 & 153 & 55.24 \\
\hline Headrest raised $30-45^{\circ}$ & 275 & 143 & 52.00 & 132 & 48.00 \\
\hline Subtotal morning & 1106 & 804 & 72.69 & 302 & 27.31 \\
\hline \multicolumn{6}{|l|}{ Afternoon } \\
\hline Use of sterile solution & 277 & 277 & 100.00 & 0 & 0 \\
\hline Respiratory therapy material change & 277 & 262 & 94.58 & 15 & 5.42 \\
\hline Physiotherapy care & 277 & 86 & 31.05 & 191 & 68.95 \\
\hline Headrest raised $30-45^{\circ}$ & 269 & 127 & 47.21 & 142 & 52.79 \\
\hline Subtotal afternoon & 1100 & 752 & 68.36 & 348 & 31.64 \\
\hline \multicolumn{6}{|l|}{ Night } \\
\hline Use of sterile solution & 285 & 284 & 99.65 & 1 & 0.35 \\
\hline Respiratory therapy material change & 285 & 275 & 96.49 & 10 & 3.51 \\
\hline Physiotherapy care* & & - & - & - & - \\
\hline Headrest raised $30-45^{\circ}$ & 281 & 130 & 46.26 & 151 & 53.74 \\
\hline Subtotal night & 851 & 689 & 80.96 & 162 & 19.04 \\
\hline Total & 3057 & 2245 & 73.44 & 812 & 26.56 \\
\hline
\end{tabular}

*No physiotherapy during the night period

Table 3 - Non-adherence rates to each specific MVAP prevention and control measure, according to work shift, Ribeirão Preto, SP, Brazil, 2009-2010

\begin{tabular}{|c|c|c|c|c|}
\hline \multirow[b]{2}{*}{ Variables } & \multicolumn{4}{|c|}{ Work shift } \\
\hline & $\begin{array}{c}\text { Morning } \\
\text { n (\%) }\end{array}$ & $\begin{array}{c}\text { Afternoon } \\
\text { n (\%) }\end{array}$ & $\begin{array}{l}\text { Night } \\
\text { n (\%) }\end{array}$ & $\begin{array}{l}\text { Total } \\
\text { n (\%) }\end{array}$ \\
\hline Headrest raised $30-45^{\circ}$ & $132(43.71)$ & $142(40.80)$ & $151(93.21)$ & $424(52.34)$ \\
\hline Physiotherapy care* & $153(50.66)$ & $191(54.89)$ & - & $344(42.36)$ \\
\hline Change of respiratory therapy material & $16(5.30)$ & $15(4.31)$ & $10(6.17)$ & $41(5.05)$ \\
\hline Use of sterile solution & $1(0.33)$ & - & $1(0.62)$ & $2(0.25)$ \\
\hline Total & $302(100)$ & $348(100)$ & $162(100)$ & $812(100)$ \\
\hline
\end{tabular}

*No physiotherapy during the night period

The raised headrest, the measured with the lowest adherence levels during the three shift, due to positioning below the recommended angle $\left(30-45^{\circ}\right)$, was the main responsible for the general non-adherence rate, mainly during the night shift (93.21\%).

Respiratory physiotherapy, only accomplished during morning and afternoon shift, corresponded to the second highest non-adherence frequency (42.36\%), which was higher during the afternoon shift (54.89\%). As for respiratory therapy material change, the morning shift showed the highest non-adherence level (16 cases).

\section{Discussion}

HI represent a significant risk for users' health.
Hence, their prevention and control are extremely important and involve hospital care qualification measures through actions that result in a better quality of health care, reduce efforts, complications and resources. Intensive care services are priority units for the development and application of quality indicators, due to the demand for countless processes involving critical patients and who, in most cases, exclusively depend on team care to survive.

According to the Manual of Hospital Infection Control Practice Quality Assessment Indicators(2), an assessment and qualification system for the control and prevention of infections caught in health services (ICHS) needs to be constantly updated, incorporating new practices and approaches that are able to handle 
the dynamic nature of the clinical care and scientific evidence evolution. In that sense, the development of systems is encouraged which use process assessments to enhance ICHS prevention and control actions.

In this study, the assessments predominantly demanded direct observation to verify the maintenance of the measures raised headrest at $30-45^{\circ}$, use of sterile solution in the mechanical ventilators' humidifiers and implementation of the respiratory therapy material change routine, in which the mechanical ventilator circuits were observed which, according to the Hospital Infection Control Commission's (HICC) protocol at the institution, should only be changed in case of visible dirt, such as blood or secretions. Regarding the assessment of respiratory physiotherapy care, this measure involved verifying its records in the patient file.

The general adherence rate, which considers the sum of the four correct measures at the same time, corresponded to $26.94 \%$. This rate varied among the shifts. This result differs from the rates found in a study at an adult ICU of a public teaching hospital, in which three process units were applied to assess the MVAP prevention and control practices, including the IRPR indicator, with a general adherence rate of $68 \%$, below the rate the author expected $(80 \%)^{(9)}$.

The calculation of isolated measures revealed that "keeping the headrest at 30-45" and "respiratory physiotherapy care" were the main factors responsible for not achieving general adherence, ranging from $46.26 \%$ to $52 \%$ and from $31.05 \%$ to $44.76 \%$, respectively. The measures that exceeded this adherence rate were the use of sterile solution, with $100 \%$ during the afternoon shift, and respiratory therapy material change (adherence rates between $94.22 \%$ and $96.49 \%$ ), demonstrating that these recommendations are well established in care delivery to patients under mechanical ventilation.

As for low adherence to the recommended headrests at $30-45^{\circ}$, it is highlighted that most beds have a goniometer (instrument used for this measurement), and that moments when patients were undergoing procedures that demanded changes in headrest height were not taken into account. Besides, the 424 cases on non-adherence to the raised headrest referred to lower degrees than recommended and occurred across all periods, with heights bordering on $20-25^{\circ}$. This data was found in another study ${ }^{(9)}$, which identified non-adherence rates of $75 \%$ (morning shift), $77.4 \%$ (afternoon) and $82.2 \%$ (night). These results show that many professionals are not accustomed to checking the headrest height with the goniometer, but merely restrict themselves to visual impression.

Critically ill patients frequently suffer from depressed consciousness levels and impaired vomiting reflex, so that contaminated secretion joins in the posterior part of the oropharynx ${ }^{(10)}$. Thus, keeping the headrest at $30-45^{\circ}$ represents benefits to reduce the risk of gastric content reflux and aspiration in patients undergoing mechanical ventilation(11). This measure is recommended in the guidelines of the Centers for Disease Control and Prevention (CDC), with evidence level II. Its application has been suggested in patients submitted to MV e/or enteral tube use since $2003^{(12-13)}$ and, although it represents a simple and low-cost non-pharmacological measure, it still lacks further incorporation by health professionals involved in care practice ${ }^{(9,14-15)}$.

A study that analyzed nurses' adherence to clinical guideline recommendations for the prevention of MVAP presents that $96.8 \%$ of professionals informed using protective gloves and gowns in view of the risk of contamination with biological material, 88.5\% applied respiratory physiotherapy to patients, $84.3 \%$ followed the institution's routine regarding mechanical ventilator circuit change, $76.4 \%$ placed the headrest at 30 $45^{\circ}$, among other measures mentioned ${ }^{(16)}$. The semirecumbent position $\left(30-45^{\circ}\right)$ was also recommended in a systematic literature review ${ }^{(17)}$, because it showed a reduction in MVAP incidence and was a low costmeasure.

A study ${ }^{(18)}$ that directly observed MVAP prevention and control measures in care practice analyzed the introduction of three new prevention measures into the MVAP incidence reduction protocol at five ICU's in the same hospital, involving medical and nursing teams. Before assessing adherence, an educational program was set up to reinforce former and new recommendations regarding the headrest raised at $30-45^{\circ}$ (with the help of an instrument to measure the headrest's degree of inclination), enteral (transpyloric) feeding, among other measures. Across a six-month period, a $51.3 \%$ reduction in MVAP rates was found, showing that the implementation and maintenance of an educational program, including audits and feedback to professionals on the collected information, contributed towards adherence to a new protocol.

As for ICU professionals' knowledge on intensive care based on clinical guidelines recommended for MVAP prevention, $49 \%$ of the interviewees referred that the respirator circuit should be changed between patients, and $13 \%$ that the humidifier of the ventilator 
should be changed once per week in the same patient. As for patients' headrest positioning at 30$45^{\circ}, 90 \%$ of participants reported that they knew the recommendation ${ }^{(19)}$.

The implementation of clinical MVAP guidelines published by the CDC was assessed in a study(10) that involved 1200 nurses, who participated in two educational events in the United States. The results showed that $34 \%$ of the nurses affirmed that they kept the headrest raised at $30-45^{\circ}$ during $75 \%$ of the day, and $52 \%$ the whole day.

An integrative literature review ${ }^{(20)}$ on MVAP prevention measures showed that the semi-recumbent position seems to play a role in MVAP prevention, although the authors appoint the need for better designed studies to recommend this measure safely and effectively.

Besides keeping the headrest raised, another assessed measure that contributed to non-adherence was physiotherapy care. In controlled studies that assessed the importance of physiotherapy for pneumonia prevention, it was observed that thoracic physiotherapy was an independent factor associated with MVAP reduction, suggesting the benefit of this technique for MVAP prevention(21-22). Other authors ${ }^{(15)}$, however, appoint that there is no evidence on the efficacy of percussion and vibration techniques to prevent MVAP.

Research on adherence to physiotherapy care is scarce. In this study, the adherence rate of $57.64 \%$ remains below the rates found for the adoption and application of clinical guideline recommendations for MVAP prevention by nurses(16), who appointed that respiratory physiotherapy was performed in $88.5 \%$ of cases. It should be highlighted that, in that study, the research population consisted of nurses and, among them, the authors found adherence to 19 nonpharmacological MVAP prevention measures.

Physiotherapy care was assessed based on patient file records, in line with IRPR orientations and, hence, procedures performed may not have been registered. Therefore, although it demands more time, direct observation is the most adequate technique to assess this item ${ }^{(9)}$.

The results obtained in this research appointed low adherence rates, mainly because the institution is a teaching hospital. Higher adherence levels were expected for specific MVAP prevention and control measures, as the HICC's activities at the research institution, and even more at the ICU under study, have been intense, mainly regarding professionals' training on adherence to infection prevention measures. It is highlighted that, months before the start of data collection, the HICC organized a recycling course for the nursing team on the main health service-associated infection and their prevention measures, evidencing the magnitude of the research findings.

One limitation in this study was the fact that no other important measures were assessed, such as adherence to hand washing, oral hygiene, assessment of the presence of condensate in the respirator circuit and humidifying filter change, which can affect a reduction in infection density rates and MVAP.

\section{Conclusions}

The adherence rate in this study corresponded to $26.94 \%$, although some isolated measures from the IRPR indicator reached rates bordering on $100 \%$. Keeping the headrest at $30-45^{\circ}$ showed the lowest adherence across all shifts assessed. Although this is a simple recommendation that demands little time, professionals' low adherence to this measure is evidenced.

Some measures analyzed are routine nursing activities inside the unit, appointing the need for systematic assessment. Besides the educative process, this involves issues related to supervision and care management at the unit, as standards, although established, have not always been incorporated into clinical practice. Thus, the health team at these units should discuss and put in practice other educative strategies.

The use of indicators can be incorporated as a useful measure to assess the quality of the services delivered, due to their easy application and reproduction.

\section{References}

1. Adami NP. A melhoria da qualidade nos serviços de enfermagem. Acta Paul Enferm. 2000;13 Suppl pt $1: 190-6$.

2. Secretaria de Estado da Saúde (SP). Divisão de Infecção hospitalar. Centro de Vigilância Epidemiológica. Controle e Prevenção de Infecção Respiratória. Manual de indicadores de avaliação da qualidade de práticas de controle de infecção hospitalar [internet]. São Paulo: Secretaria de Estado da Saúde; 2006 [acesso 16 set 2009]. Disponível em: http://www.cve.saude.sp.gov.br/ htm/ih/IH_MANUALFAPESP06.pdf

3. Donabedian A. Evalución de la calidad de la atención médica. In: White $\mathrm{KL}$, Frank J, organizadores. Investigaciones sobre servicios de salud: una antologia. Washington (DC): OPAS; 1992. p. 382-404. 
4. Moura MEB, Campelo SMA, Brito FCP, Batista OMA, Araújo TME, Oliveira ADS. Infecção hospitalar: estudo de prevalência em um hospital público de ensino. Rev Bras Enferm. [internet]. 2007 [acesso 16 jun 2010];60(4):416-21. Disponível em: http://www.scielo. br/scielo.php?script=sci_arttext\&pid=S0034716720070 00400011\&lng =en\&nrm =iso

5. Fernandes AT, Fernandes MOV, Ribeiro N Filho. Infecção hospitalar e suas interfaces na área da saúde. São Paulo: Atheneu; 2000. 2 v.

6. Guimarães MMQ, Rocco JR. Prevalence of ventilatorassociated pneumonia in a university hospital and prognosis for the patients affected. J Bras Pneumol. 2006;32(4):339-46.

7. Oliveira AC, Kovner CT, Silva RS. Infecção hospitalar em unidade de tratamento intensivo de um hospital universitário brasileiro. Rev. Latino-Am. Enfermagem. [internet]. 2010 [acesso 21 jul 2010];18(2):233-9. Disponível em: http:// www.sielo.br/pdf/rlae/v18n2/pt_14.pdf.

8. Agência Nacional de Vigilância Sanitária (ANVISA) (BR). Unidade de Investigação e Prevenção das Infecções e dos Eventos Adversos. Gerência Geral de Tecnologia em Serviços de Saúde. Infecções do trato respiratório: orientações para prevenção de infecções relacionadas à assistência à saúde [internet]. Brasília (DF): ANVISA; out. 2009 [acesso 25 abr 2010]. Disponível em: http:// www.anvisa.gov.br/servicosaude/controle/manual_\%20 trato_respirat\%F3rio.pdf.

9. Menezes IRSC. Avaliação da conformidade de práticas de controle e prevenção da pneumonia associada à ventilação mecânica em um hospital público de ensino [Dissertação de mestrado]. São Paulo (SP): Escola de Enfermagem, Universidade de São Paulo; 2009. 164 p.

10. Cason CL, Tyner T, Saunders S, Broome L. Nurses implementation of guidelines for ventilator-associated pneumonia from the Centers for Disease Control and Prevention. Am J Crit Care. 2007;16(1):28-38.

11. Grap MI, Munro CL. Ventilator-associated pneumonia: clinical significance and implications for nursing. Heart Lung. 1997;26(6):419-29.

12. Tablan OC, Anderson LJ, Besser R, Bridges C, Hajjeh R. Guidelines for preventing health-care--associated pneumonia, 2003. Recommendations of Centers for Disease Control and Prevention and the Healthcare Infection Control Practices Advisory Committee. MMWR [internet]. 2004 [acesso 21 maio 2007];53(3):1-36. Disponível em: http://www.cdc.gov/mmwr/preview/ mmwrhtml/rr530321.htm.

13. Coffin SE, Klompas M, Classen D, Arias, KM, Podgorny $\mathrm{K}$, Anderson DJ, et al. Strategies to prevent ventilator- associated pneumonia in acute care hospitals. Infect Control Hosp Epidemiol [internet]. 2008 [acesso 20 nov 2009];29 Suppl 1:S31-40. Disponível em: http://www. journals.uchicago.edu/doi/pdf/10.1086/591062

14. Drakulovic MB, Torres A, Bauer $\Pi$, Nicolas, JM, Noguê $S$, Ferrer $M$. Supine body position as a risk factor for nosocomial pneumonia in mechanically ventilated patients: a randomised trial. Lancet. 1999;354(9193):1851-8.

15. Miguel-Roig C, Picó-Secura P, Huertas-Linero C, Pastor-Martínez M. Cuidados de enfermería en la prevención de la neumonía asociada a ventilación mecánica. Revisión sistemática. Enferm Clín. [internet] 2006 [acesso 03 set 2007];16(5):245-54. Disponível em: http://www.dayama.es

16. Ricart M, Lorente C, Diaz E, Kollef MH, Rello J. Nursing adherence with evidence-based guidelines for preventing ventilator-associated pneumonia. Crit Care Med. 2003;31(11):2693-6.

17. Dodek P, Keenan S, Cook D, Heyland D, Jacka M, Hand $L$, et al. Evidence-based clinical practice guideline for the prevention of ventilator-associated pneumonia. Ann Intern Med. 2004;141(4):305-13.

18. Baxter AD, Allan J, Bedard J, Tucker SM, Slivar $\mathrm{S}$, Langill $\mathrm{M}$, et al. Adherence to simple and effective measures reduces the incidence of ventilator-associated pneumonia. Can J Anaesth. 2005;52(5):535-41.

19. Blot SI, Labeau S, Vandijck D, Van Aken P, Claes B. Executive Board of the Flemish Society for Critical Care Nurses. Evidence-based guidelines for the prevention of ventilator-associated pneumonia: results of a knowledge test among intensive care nurses. Intensive Care Med. 2007;33(8):1463-7.

20. Beraldo CC. Prevenção da pneumonia associada à ventilação mecânica: revisão integrativa [Dissertação de mestrado]. Ribeirão Preto (SP): Escola de Enfermagem de Ribeirão Preto da Universidade de São Paulo; 2008. 160 p.

21. Ntoumenopoulos G, Presneill JJ, McElholum M, Cade JF. Chest physiotherapy for the prevention of ventilator-associated pneumonia. Intensive Care Med. $2002 ; 28(7): 850-6$.

22. Jerre G, Silva TJ, Beraldo MA, Gastaldi A, Kondo C, Leme F. III Consenso Brasileiro de Ventilação Mecânica. Fisioterapia no paciente sob ventilação mecânica. J Bras Pneumol. 2007;33 Suppl 2:S142-S50. 